\title{
Corrigendum: Core competencies for pharmaceutical physicians and drug development scientists
}

\section{Honorio Silva *, Peter Stonier, Fritz Buhler, Jean P. Deslypere, Domenico Criscuolo, Gerfried Nell, Joao Massud, Stewart Geary, Johanna Schenk, Sandor Kerpel-Fronius, Greg Koski, Norbert Clemens, Ingrid Klingmann, Gustavo Kesselring, Rudolf van Olden and Dominique Dubois}

International Federation of Associations of Pharmaceutical Physicians and Pharmaceutical Medicine, Special Secretariat Service, Woerden, Netherlands *Correspondence: honorio.silva@globecpd.org

Edited and reviewed by:

Iñaki Gutiérrez-Ibarluzea, Nursing School, Spain

Keywords: pharmaceutical medicine, medicines development, drug development scientists, pharmaceutical physicians, corrigendum, competency based education, learning outcomes, core competencies

\section{A corrigendum on}

Core competencies for pharmaceutical physicians and drug development scientists

by Silva, H., Stonier, P., Buhler, F., Deslypere, J. P., Criscuolo, D., Nell, et al. (2013). Front. Pharmacol. 4:105. doi: 10.3389/fphar.2013.00105

The total number of competencies mentioned in the Abstract and pages 4 and 5 of the paper are erroneously reported as 60. The actual number is 57. Apologies for the involuntary mistake and confusion created.

Conflict of Interest Statement: The authors declare that the research was conducted in the absence of any commercial or financial relationships that could be construed as a potential conflict of interest.

Received: 11 November 2014; accepted: 22 December 2014; published online: 15 January 2015.

Citation: Silva H, Stonier P, Buhler F, Deslypere JP, Criscuolo D, Nell G, Massud J, Geary S, Schenk J, Kerpel-Fronius S, Koski G, Clemens N, Klingmann I, Kesselring G, van Olden $R$ and Dubois D (2015) Corrigendum: Core competencies for pharmaceutical physicians and drug development scientists. Front. Pharmacol. 5:297. doi: 10.3389/fphar.2014.00297

This article was submitted to Pharmaceutical Medicine and Outcomes Research, a section of the journal Frontiers in Pharmacology.

Copyright (c) 2015 Silva, Stonier, Buhler, Deslypere, Criscuolo, Nell, Massud, Geary, Schenk, Kerpel-Fronius, Koski, Clemens, Klingmann, Kesselring, van Olden and Dubois. This is an open-access article distributed under the terms of the Creative Commons Attribution License (CC BY). The use, distribution or reproduction in other forums is permitted, provided the original author $(s)$ or licensor are credited and that the original publication in this journal is cited, in accordance with accepted academic practice. No use, distribution or reproduction is permitted which does not comply with these terms. 